\title{
Efficacy and Safety of Surgery for Lumbar Disc Herniation in Patients Aged 80 and Older
}

\author{
Seksen Yaş ve Üzeri Hastalarda Lomber Disk Hernisi Cerrahisinin \\ Etkinliği ve Güvenliliği
}

Hai NIE, Dianming JIANG, Yunsheng OU, Zhengxue QUAN, Chunhong BAI, Hong AN

The First Affiliated Hospital, Chongqing Medical University, Department of Spine Surgery, Chongqing 400016, China

Correspondence address: Hong AN / E-mail: anhong1106@sohu.com

\begin{abstract}
AIM: To evaluate the efficacy and safety of surgery for lumbar disc herniation in patients aged 80 or older.

MATERIAL and METHODS: Operative time (OT), intraoperative estimated blood loss (EBL), length of hospital stay (LOS), and complication rate (CR) were used to assess safety of surgery. The Visual Analog Scale (VAS), the Oswestry disability index (ODI) and the North American Spine Society Outcome Questionnaire (NASS-Q) were used to evaluate the clinical effectiveness.

RESULTS: There were significant differences between the very elderly and the middle-aged group in $L O S(P<0.001)$, but not in OT, EBL and CR (all $P>0.05$ ). The preoperative, post-operative and final follow up VAS and ODI scores were not significantly different between the two groups (each $\mathrm{P}>0.05$ ). However, the VAS and ODI scores were significantly improved after surgery and at ultimate follow up compared with those before surgery (all $\mathrm{P}<0.001$ ). Satisfaction with outcome was expressed by $39(86.7 \%)$ of 45 very elderly patients.
\end{abstract}

CONCLUSION: Conventional laminectomy, discectomy and/or spinal fusion surgery is a feasible, safe and effective treatment in patients over age 80 with lumbar disc herniation compared with middle-aged patients.

KEYWORDS: Lumbar disc herniation, Retrospective study, Lumbar discectomy, Octogenarian, Clinical outcomes

Öz

AMAÇ: Seksen yaş ve üzeri hastalarda lomber disk hernisi cerrahisinin etkinliği ve güvenliliğini değerlendirmek.

YÖNTEM ve GEREÇ: Cerrahinin güvenliliğini değerlendirmek için ameliyat süresi, kan kaybı, hastanede yatış süresi, ve komplikasyon oranı kullanıldı. Görsel Ağrı Skalası (VAS), Oswestry dizabilite endeksi (ODI) ve North American Spine Society Outcome Questionnaire (NASS-Q) klinik etkinliği değerlendirmek amacıyla kullanıldı.

BULGULAR: Çok yaşılıar ile orta yaş grupları arasında hastanede yatış süresinde belirgin fark vardı $(P<0.001)$, fakat ameliyat süresinde, kan kaybında, ve komplikasyon oranında belirgin farklılık yoktu (hepsi $P>0.05$ ). Preoperatif, postoperatif ve takip VAS ve ODI skorları iki grup arasında belirgin farklı değildi (herbiri $P>0.05$ ). Bununla beraber VAS ve ODI skorları cerrahiden sonra ve en son takipte ameliyat öncekine göre belirgin biçimde daha iyiydi (hepsi P < 0.001). Sonuçtan tatminkarlık çok yaşlı 45 hastanın 39 u (\%86.7) tarafından belirtildi.

SONUÇ: Konvansyonel laminektomi, diskektomi ve/veya spinal füzyon cerrahisi 80 yaş üzeri hastalarda orta yaşlılarla karşılaştıııldığında uygulanabilir güvenli ve etkin bir tedavidir.

ANAHTAR SÖZCÜKLER: Lomber disk hernisi, Retrospektif çalışma, Lomber diskektomi, Oktogenaryan, Klinik sonuçlar

\section{INTRODUCTION}

Life expectancy has been steadily rising over the last century. As recently as 2008, the Chinese Vital Statistics estimated that there are over 17 million people in the People's Republic of China (1.4\% of the population) 80 years old or older (11). The very elderly are a small but rapidly growing segment of the Chinese population. This group has been noted as the orthopedic surgery population and represents a concern as the very elderly patients have multiple risk factors including general condition, comorbidity and pathophysiological changes which may result in more adverse outcomes after surgery. Advanced age might therefore be considered a contraindication to elective spine surgery. Treatment of spinal degenerative disorders in the very elderly is a challenge for the practitioner. Spinal surgery for the very elderly requires the orthopaedic surgeon to consider the patient as more than just an older individual and demands that the entire perioperative milieu be examined and its issues resolved.

Lumbar disc herniation is less frequent in the very elderly although it occurs at every adult age. As the number of elderly people is increasing steadily, lumbar disc herniation in the very elderly has become more common, and the incidence of indications to operate on those patients for this lumbar spinal disorder has also increased. However, there is little 
information about acute and long-term outcomes of surgery for lumbar disc herniation in octogenarians and the influence of age on the outcome after lumbar surgery still remains a matter of controversy $(7,12,15)$.

The present study evaluated the feasibility, efficacy and safety of surgical treatment of lumbar disc herniation in patients over the age of 80 years compared with middle-aged patients.

\section{MATERIAL and METHODS}

Forty five patients older than 80 years (mean age, 84.1 years), defined as belonging to the very elderly group, who were surgically treated between January 2004 and October 2009 for a CT or MRI-verified one-level disc herniation that correlated with the patients' symptoms were identified. During the same period, there were 434 patients aged between 40 and 60 years with lumbar disc herniation undergoing the same surgical procedure, and 45 patients from this group (mean age, 49.1 years) were randomly chosen to serve as the control group (middle-aged group) for comparison. The diagnosis of lumbar disc herniation depended upon typical symptoms such as shooting pain in the lower extremity, neurological examination revealing abnormal reflexes, positive straight leg raising test and abnormal sensation in the foot or leg. All the patients underwent an MRI scan to confirm the diagnosis. Persistent signs and symptoms of radiculopathy that lasted for at least 12 weeks were present and unremitting with conservative treatment such as medication, physical therapy, and injections before surgery. We included only patients who underwent surgery at a single level for the first time. Patients with multiple herniations were included if only one of the herniations was considered symptomatic or if only one was planned to be operated on. We excluded patients with severe comorbid conditions and obvious spinal deformity. The surgical procedure was a conventional single-level laminectomy, discectomy and/or spinal fusion surgery by welltrained orthopedic spine surgeons. An intraoperative crosstable lateral radiograph was used to identify the appropriate level. The nerve root was completely decompressed and mobile. Surgical contraindications included multiple organ dysfunction or failure, severe malnutrition, acute infection, and other medical conditions where the patients were unable to tolerate surgery by preoperative surgical risk assessment.

\section{Perioperative management}

It is crucial to determine the physiological changes related to aging and to correctly evaluate and manage the related comorbidities and disabilities in the perioperative period. Before surgery, patients were required to have a complete physical examination and routine preoperative testing. The patient was advised to stop smoking at least a week before surgery and to take nothing by mouth after midnight before the procedure. Anticoagulants, antiplatelet drugs and arthritis medications should be discontinued 7 to 10 days before surgery. Strict blood glucose and blood pressure control should be pursued more seriously throughout the perioperative period. In addition, early nutritional support in the undernourished and malnourished elderly is very important.
After surgery, all subjects initially received absolute bed rest. Most patients will remain in the hospital for 2 to 10 days after the procedure. Active measures should be taken to prevent infection, deep venous thrombosis, severe pain, and to get the lungs back to normal function. Patients were educated on lumbar stretching and core muscle strengthening as early as possible after surgery. Patients were discharged to either home or rehabilitation facilities. A second follow-up examination was usually done 2 and 8 weeks after surgery.

\section{Outcome measures}

The demographic characteristics collected included age, gender, comorbid conditions, duration of symptoms, followup time, level and classification of lumbar disc herniation (Table I).

Operative time (OT), intraoperative estimated blood loss (EBL), length of hospital stay (LOS), and complication rate (CR) were chosen to assess the safety of surgery. OT and EBL were collected from anesthetic records, in which the intraoperative EBL was recorded as blood loss estimated in sponges and drapes plus the volume of salvaged blood in the cell saver, or suction container if a cell saver was not used. The LOS was determined from admission to discharge. In our work, common complications included wound infection, wound haematoma, cerebrospinal fluid leak.

The postoperative mean follow-up period for clinical outcome variables was 19.7 months (range, 12 to 30 months). Primary outcome data included the Visual Analog Scale (VAS), as described in detail by Scott and Huskisson17, and the Oswestry disability index (ODI) 6, which were collected in an independent examiner not affiliated with the study preoperatively, at the postoperative second week, and at the final follow-up. The secondary outcome was patient satisfaction with current symptoms and care and return to active duty. The patient satisfaction was evaluated using the North American Spine Society Outcome Questionnaire (NASS-Q) with Patient Satisfaction Index (PSI) (3). A score of 4 or 5 was regarded as reflecting a satisfactory outcome. Questionnaires were sent to patients by investigators other than the primary surgeon for the final follow-up assessment.

\section{Statistical Analysis}

All statistical analyses were conducted using SPSS software (version 16.0; SPSS Inc., Chicago, Illinois). Continuous variables were expressed as mean (standard deviation, SD), and categorical variables as a percentage of the number of patients. The two independent samples test was used to analyze differences between groups for continuous data, and the Mann-Whitney $U$ test and the Chi-square test for categorical data. A P value of less than 0.05 was considered statistically significant.

\section{RESULTS}

\section{Demographic characteristics}

Patient demographic data are listed in Table I. The major preoperative medical conditions included hypertension, diabetes mellitus, pulmonary disease, and joint problems. 
The other comorbidities comprised stroke, osteoporosis, cancer, heart disease, chronic renal insufficiency, hepatic dysfunction, dementia, hyperlipemia, transient ischemic attacks, peripheral vascular disease, and drug dependency. In the very elderly group, 11 patients (24.4\%) had no comorbidity and 6 patients (13.3\%) had two or three comorbid conditions. The most common levels for a herniated disc was L4-5. Sequestered extrusion was the main type of lumbar disc herniation. However, the most common levels for a herniated disc were L5-S1 and extrusion was the main type of lumbar disc herniation in the middle-aged group. The very elderly group had a significantly higher incidence of comorbidities when the two groups were compared.

\section{Safety assessment}

The safety analysis of surgery in both groups is shown in Table II. There were statistically significant differences in LOS $(P<0.001)$ between the elderly and the middle-aged group, but not in OT $(P=0.142)$, EBL $(P=0.243)$ and $C R(P=0.308)$ detailed in Table II. Complications occurred in $6.7 \%(n=3)$ of the patients in the very elderly group and $2.2 \%(n=1)$ of the patients in the middle-aged group. The difference in overall complications was not significantly different between the two groups. All of the intraoperative, postoperative and long-term complications were resolved uneventfully. No intraoperative or hospital deaths occurred.

Table I: Characteristics of Patients Who were Treated Surgically for Lumbar Disc Herniation

\begin{tabular}{|c|c|c|}
\hline & \multicolumn{2}{|c|}{ Patients, No. (\%) } \\
\hline & Middle-aged group(n=45) & Very elderly group(n=45) \\
\hline Age, Mean (SD), yr & $49.1(6.3)$ & $84.1(2.2)$ \\
\hline Women & $19(42.2)$ & $21(46.7)$ \\
\hline \multicolumn{3}{|l|}{ Comorbid conditions } \\
\hline $\begin{array}{l}\text { Hypertension } \\
\text { Joint problem } \\
\text { Diabetes mellitus } \\
\text { Pulmonary disease } \\
\text { Others† }\end{array}$ & $\begin{aligned} 8 & (17.8) \\
7 & (15.6) \\
6 & (13.3) \\
1 & (2.2) \\
10 & (22.2)\end{aligned}$ & $\begin{array}{l}13(28.9) \\
16(35.5) * \\
10(22.2) \\
7(15.6)^{*} \\
18(40.0)\end{array}$ \\
\hline Duration of symptoms, Mean(SD), mo & $3.9(1.2)$ & $4.7(1.8)$ \\
\hline Pain with straight leg raise $\neq$ & $34(75.6)$ & $31(68.9)$ \\
\hline \multicolumn{3}{|l|}{ Herniation level } \\
\hline $\begin{array}{l}\mathrm{L}_{2-3} \& \mathrm{~L}_{3-4} \\
\mathrm{~L}_{4-5} \\
\mathrm{~L}_{5}-\mathrm{S}_{1}\end{array}$ & $\begin{array}{c}3(6.7) \\
24(53.3) \\
18(40.0)\end{array}$ & $\begin{array}{c}4(8.9) \\
16(35.5) \\
25(55.6)\end{array}$ \\
\hline \multicolumn{3}{|l|}{ Herniation type } \\
\hline $\begin{array}{l}\text { Protruding } \\
\text { Extruded } \\
\text { Sequestered }\end{array}$ & $\begin{array}{r}9(20.0) \\
17(37.8) \\
19(42.2)\end{array}$ & $\begin{array}{r}7(15.5) \\
30(66.7) \\
8(17.8)\end{array}$ \\
\hline Duration of follow-up, Mean (SD), mo & $20.2(4.2)$ & $19.1(4.7)$ \\
\hline
\end{tabular}

* $P<0.05$ versus middle-aged group.

t indicates problems related to stroke, osteoporosis, cancer, heart disease, chronic renal insufficiency, hepatic dysfunction, dementia, hyperlipemia, transient ischemic attacks, peripheral vascular disease, drug dependency.

\# The straight leg raise test is defined positive if the patient feel pains that travels down his leg when it is lifted to the $30^{\circ}$ to $70^{\circ}$ range.

Table II: Safety Analysis of Surgery in the Very Elderly Patient with Lumbar Disc Herniation, Mean (SD)

\begin{tabular}{l|c|c|c|c|} 
& OT(min) & EBL $(\mathrm{ml})$ & CR (n, \%)t & LOS (days) \\
\hline very elderly group & $79 \pm 34$ & $93 \pm 62$ & $3(6.7)$ & $8 \pm 2$ \\
\hline middle-aged group & $86 \pm 42$ & $104 \pm 55$ & $1(2.2)$ & $3 \pm 1$ \\
\hline P value & 0.142 & 0.243 & 0.308 & $<0.001$
\end{tabular}

Abbreviation: $\boldsymbol{O T}=$ operative time; $\mathbf{E B L}=$ intraoperative estimated blood loss; $\mathbf{L O S}=$ length of hospital stay; $\boldsymbol{C R}=$ complication rate.

t Any reported complications up to 8 weeks postoperatively. Complications consisted of 1 dural tear at surgery, 1 superficial wound infection, 1 wound haematoma in the elderly group, and 1 superficial wound infection in the middle-aged group. 


\section{VAS and ODI}

All patients were assigned pain-scale scores and ODI prospectively, before and after surgery and final follow up (Table III). A decrease of greater than 2 points on the VAS was observed in $82.2 \%$ (37/45) of the very elderly group and $80.0 \%(36 / 45)$ of the middle-aged group at the final follow up period. The differences in VAS score between the groups were not significant. About $84.4 \%$ (38/45) of the very elderly group and $77.8 \%(35 / 45)$ of the middle-aged group had a decrease in Oswestry index of at least $25 \%$. There was no significant difference in Oswestry disability index between the two groups.

\section{Patient Satisfaction}

As shown in Table IV, 39 (86.7\%) patients stated that they would undergo the same surgery for the same result (Patient Satisfaction Index of 4 or 5) in the very elderly group in the last follow-up period. Thirty eight (84.4\%) of 45 patients reported subjective satisfaction in the middle-aged group. We found no statistically significant difference between the groups $(P=0.761)$.

\section{DISCUSSION}

As the Chinese population ages (11), orthopedic surgeons will be faced with treating an increasing number of elderly patients with lumbar disc herniation. The elderly patients need special attention because they may have inadequate functional reserve of important organ systems when subjected to the stress of surgery or its complications. We therefore decided to conduct a retrospective review of patients 80 years or older who underwent surgery at our spine center, in an attempt to define the surgical safety and efficacy of such patients compared with middle-aged patients.
Most reports on the outcome of lumbar discectomy for herniation show good results and safety $(4,9-10,13,18,20)$. Many of the patients in these reports were young, middle-aged or younger than 80 years old $(7,9-10,13,18,20)$; few reports have evaluated how very elderly patients respond to lumbar discectomy. The normal ageing process causes changes in all structures of the lumbar spine, many contributing to central spinal stenosis which affects the elderly, and disc herniation which is most common in middle-aged patients (2). Every patient in our study had a demonstrable disc herniation as the cause of lower back pain and/or sciatica. Sequestrated herniation at a high level was more common in the very elderly group, and the degenerative changes were obviously more pronounced than in the middle-aged group. These characteristics of lumbar disc herniations in the very elderly patients were assumed to result from severe disc degeneration (5).

In our current study, we were able to directly compare the outcomes of patients 80 years or older with a middle-aged patient cohort specifically with lumbar disc herniation. The very elderly population was found to have a significantly increased number of preoperative comorbid conditions. Although some studies $(1,8,19)$ have shown that advanced age is not a significant factor in poor outcomes after spine surgery, increasing comorbidities increase the risk of morbidity or complication.We were very careful about surgical indications and surgical technique in the very elderly population in the present work and observed that they had a slightly higher incidence of adverse events, but without any significant difference in complications compared with the middle-aged group. The complication rate in this study was similar to those reported in other studies $(14,21)$. Analysis revealed that the very elderly patient population had a significantly increased length of hospital stay as compared with the middle-aged

Table III: Postoperative Changes in VAS Back Pain, VAS Leg Pain and ODI Scores, Mean (SD)

\begin{tabular}{|c|c|c|c|c|c|c|}
\hline & & preoperative & postoperative & follow-up & $\begin{array}{c}\text { P(Postoperative/ } \\
\text { preoperative) }\end{array}$ & $\begin{array}{l}\text { P(follow-up/ } \\
\text { preoperative) }\end{array}$ \\
\hline VASt & $\begin{array}{l}\text { very elderly } \\
\text { middle-aged }\end{array}$ & $\begin{array}{l}5.2(1.0) \\
4.9(1.0)\end{array}$ & $\begin{array}{l}2.5(0.8) \\
2.6(0.9)\end{array}$ & $\begin{array}{l}2.6(1.0) \\
2.8(1.2)\end{array}$ & $\begin{array}{l}<0.001 \\
<0.001\end{array}$ & $\begin{array}{l}<0.001 \\
<0.001\end{array}$ \\
\hline ODIキ & $\begin{array}{l}\text { very elderly } \\
\text { middle-aged }\end{array}$ & $\begin{array}{l}54.4(11.1) \\
53.6(11.6)\end{array}$ & $\begin{array}{l}18.8(4.9) \\
19.1(4.6)\end{array}$ & $\begin{array}{l}20.0(8.4) \\
19.8(7.8)\end{array}$ & $\begin{array}{l}<0.001 \\
<0.001\end{array}$ & $\begin{array}{l}<0.001 \\
<0.001\end{array}$ \\
\hline
\end{tabular}

Abbreviation: $\mathbf{V A S}=$ Visual Analogue Scale; $\mathbf{O D I}=$ Oswestry Disability Index. t The intensity of pain was indicated on a visual analogue scale, with 0 representing no pain and 10 the worst pain ever experienced. \#Oswestry disability index is a questionnaire used in the management of spinal disorders, which allows patients to estimate their disability as to pain intensity, personal care, lifting, walking, sitting, standing, sleeping, sexual activity, social life and travelling. Scores range from 0 to 100 , with lower scores indicating less severe symptoms.

Table IV: Patient Satisfaction with Outcome of Surgery in the Very Elderly, No. (\%)

\begin{tabular}{|c|c|c|c|c|c|}
\hline PSI & 1 & 2 & 3 & 4 \\
\hline very elderly group & $1(2.2)$ & $2(4.5)$ & $3(6.7)$ & $15(33.3)$ & $24(53.3)$ \\
\hline middle-aged group & $2(4.5)$ & $1(2.2)$ & $4(8.9)$ & $19(42.2)$ & $19(42.2)$ \\
\hline
\end{tabular}

PSI = patient satisfaction index: Would you like to have the same treatment for the same ailment?

PSI $\mathbf{1}$ = definitely not $\mathbf{2}=$ probably not; $\mathbf{3}=$ not sure; $\mathbf{4}=$ probably yes; $\mathbf{5}=$ definitely yes. 
patient population. There were no significant differences in OT, EBL and CR between two groups. Therefore, the results suggest that laminectomy, discectomy and/or spinal fusion surgery is a safe and acceptable treatment without significant morbidity for selected octogenarians.

The postoperative and last follow-up VAS and ODI scores in the very elderly patients were similar to those in middleaged patients. The very elderly patients were found to have their symptoms improved with lumbar disc herniation after surgical treatment. Besides the VAS scores and ODI scores, we also investigated patient satisfaction in both groups at the ultimate follow-up. Findings showed that $86.7 \%$ patients aged over 80 reported a general satisfaction after surgery, which is basically consistent with a previous finding reported by Saruhashi et al (16) who reported that $89.4 \%$ of patients were satisfied with their operation. The results achieved indicate that standard lumbar discectomy has the same efficacy in very elderly patients with lumbar disc degenerative disease as in middle-aged patients.

There are several weaknesses in this study. All the procedures were performed by a single spine center and the results therefore need to be confirmed in a multicenter study. In addition, the follow-up period was short (12-30 months) and the long-term outcome of surgical management in octogenarians with lumbar disc disorder cannot be ensured. Most patients rejected to participate in a prospective randomized controlled trial, and we therefore only followed the cohort of operated patients. The follow-up was available from all patients that were still alive.

\section{CONCLUSIONS}

In conclusion, careful attention to patient selection, surgical indications and aggressive perioperative management is always required for the successful treatment of the very elderly population. Conventional laminectomy, discectomy and/or spinal fusion surgery in patients over age 80 is a feasible, safe and effective treatment without significant morbidity compared with middle-aged patients. There was a long-lasting improvement and high patient satisfaction after lumbar discectomy in the majority of very elderly patients. In our opinion, this study may provide some guidance in clinicalpractical decisions for very elderly patients with single level lumbar disc herniation. Further research should focus on appropriate treatment of octogenarians with multiple level disc herniation.

\section{REFERENCES}

1. Cloyd JM, Acosta FL, Jr. \& Ames CP: Complications and outcomes of lumbar spine surgery in elderly people: A review of the literature. J Am Geriatr Soc 56: 1318-1327, 2008

2. Cummins J, Lurie JD, Tosteson TD, Hanscom B, AbduWA, Birkmeyer $\mathrm{NJ}$, Herkowitz $\mathrm{H}$, Weinstein J: Descriptive epidemiology and prior healthcare utilization of patients in the Spine Patient Outcomes Research Trial's (SPORT) three observational cohorts: Disc herniation, spinal stenosis, and degenerative spondylolisthesis. Spine 31: 806-814, 2006

3. Daltroy LH, Cats-Baril WL, Katz JN, Fossel AH, Liang MH: The North American spine society lumbar spine outcome assessment Instrument: reliability and validity tests. Spine 21: 741-749, 1996
4. Daneyemez M, Sali A, Kahraman S, Beduk A, Seber N: Outcome analyses in 1072 surgically treated lumbar disc herniations. Minim Invasive Neurosurg 42: 63-68, 1999

5. Elfering $A$, Semmer $N$, Birkhofer $D$, Zanetti $M$, Hodler J, Boos $N$ : Risk factors for lumbar disc degeneration: A 5-year prospective MRI study in asymptomatic individuals. Spine 27: 125-134, 2002

6. Fairbank JC, Pynsent PB: The Oswestry Disability Index. Spine 25: 2940-2952; discussion 2952, 2000

7. Fujii K, Henmi T, Kanematsu $Y$, Mishiro T, Sakai T: Surgical treatment of lumbar disc herniation in elderly patients. J Bone Joint Surg Br 85: 1146-1150, 2003

8. Hart RA, Prendergast MA:Spine surgery for lumbar degenerative disease in elderly and osteoporotic patients. Instr Course Lect 56: 257-272, 2007

9. Kumar R, Kumar V, Das NK, Behari S, Mahapatra AK: Adolescent lumbar disc disease: Findings and outcome. Childs Nerv Syst 23: 1295-1299, 2007

10. Mariconda M, Galasso O, Secondulfo V, Rotonda GD, Milano C: Minimum 25-year outcome and functional assessment of lumbar discectomy. Spine 31: 2593-2599; discussion 2600-2591, 2006

11. National Bureau of Statistics of China: Population by Age and Sex 2008. Available at: http://www.stats.gov.cn/tjsj/ndsj/2009/ indexeh.htm. Accessed 5 June 2010

12. Nygaard OP, Kloster $R$, Solberg T: Duration of leg pain as a predictor of outcome after surgery for lumbar disc herniation: a prospective cohort study with 1-year follow up. J Neurosurg 92: 131-134, 2000

13. Papadopoulos EC, Girardi FP, Sandhu HS, Sama AA, Parvataneni HK, O'Leary PF, Cammisa FP Jr: Outcome of revision discectomies following recurrent lumbar disc herniation. Spine 31: 1473-1476, 2006

14. Peul WC, van den Hout WB, Brand R, Thomeer RT, Koes BW: Prolonged conservative care versus early surgery in patients with sciatica caused by lumbar disc herniation: Two year results of a randomised controlled trial. BMJ 336: 1355-1358, 2008

15. Rothoerl RD, Woertgen $C$, Holzschuh $M$, Schlaier J: Are there differences in the symptoms, signs and outcome after lumbar disc surgery in the elderly compared with younger patients? $\mathrm{Br}$ J Neurosurg 12: 250-253, 1998

16. Saruhashi Y, Mori K, Katsuura A, Takahashi S, Matsusue Y, Hukuda $\mathrm{S}$ : Evaluation of standard nucleotomy for lumbar disc herniation using the Love method: results of follow-up studies after more than 10 years. Eur Spine J 13: 626-630, 2004

17. Scott J, Huskisson EC: Graphic representation of pain. Pain 2: 175-184, 1976

18. Smorgick Y, Floman Y, Millgram MA, Anekstein Y, Pekarsky I, Mirovsky Y: Mid- to long-term outcome of disc excision in adolescent disc herniation. Spine J 6: 380-384, 2006

19. Sokolowski MJ, Jackson AP, Haak MH, Meyer PR Jr, Sokolowski MS: Acute mortality and complications of cervical spine injuries in the elderly at a single tertiary care center. J Spinal Disord Tech 20: 352-356, 2007

20. Weinstein JN, Lurie JD, Tosteson TD, Tosteson AN, Blood EA, Abdu WA, Herkowitz $\mathrm{H}$, Hilibrand A, Albert T, Fischgrund J: Surgical versus nonoperative treatment for lumbar disc herniation: Four-year results for the Spine Patient Outcomes Research Trial (SPORT). Spine 33: 2789-2800, 2008

21. Weinstein JN, Tosteson TD, Lurie JD, Tosteson AN, Hanscom B, Skinner JS, Abdu WA, Hilibrand AS, Boden SD, Deyo RA: Surgical vs nonoperative treatment for lumbar disk herniation: The Spine Patient Outcomes Research Trial (SPORT): A randomized trial. JAMA 296: 2441-2450, 2006 